\title{
EXPERIMENT AND FE ANALYSIS ON SHEAR RESISTANCE OF COLD-FORMED STEEL STUD ASSEMBLED WALL IN RESIDENTIAL STRUCTURE
}

\author{
Xuhong Zhou ${ }^{1,2}$, Yongjun $\mathrm{He}^{1, *}$, Yu Shi ${ }^{3}$, Tianhua Zhou ${ }^{4}$ and Yongjian Liu ${ }^{4}$ \\ ${ }^{I}$ Professor, College of Civil Engineering, Hunan University, Changsha, 410082, China \\ ${ }^{2}$ Professor, Lanzhou University, Lanzhou, 730000, China \\ ${ }^{3}$ Lecturer, ${ }^{4}$ Professor, Chang'an University, Xi'an, 710064, PR China \\ *(Corresponding author: E-mail: hyj0087@163.com)
}

Received: 1 December 2009; Revised: 22 January 2010; Accepted: 18 February 2010

\begin{abstract}
In this paper, experiment and finite element (FE) method are adopted to study the shear resistance of cold-formed steel stud walls in low-rise residential structures. Firstly, the shear resistance of the cold-formed steel stud assembled walls under monotonic loading is tested. The test models, including walls with single-sided gypsum sheathing, walls with single-sided oriented strand board sheathing, and walls with gypsum sheathing on the back and oriented strand board on the front, are made in full scale of engineering project. The test apparatus, test method, and the failure process of the specimens are introduced in detail. Then, based on the ANSYS program, the FE model of the cold-formed steel stud walls considering geometric large deformation and materials nonlinearity is presented. The walls are simulated as shell elements. The studs as well as the tracks are simply connected, and the screws connecting the sheathings to the frame are modeled by coupling methods. The validity of the FE method is verified, and then a series of parametric analyses are carried out. All this work will provide guidance in theory for practical application of this kind of wall.
\end{abstract}

Keywords: Cold-formed steel; Assembled wall; Shear resistance; Experimental research; Finite element analysis

\section{INTRODUCTION}

Assembled walls are the main load-bearing members of the cold-formed steel residential buildings, and the cold-formed steel stud walls are assembled by C-shaped steel studs (channel with lip flanges), U-shaped tracks(channel without lip flanges), gypsum board, and oriented strand board (OSB), which are connected by self-piercing or self-drilling screws(NASFA [1]).

The shear resistance of the cold-formed steel stud walls is associated with many factors, such as materials of studs and sheathing, screw spacing, height-width ration of wall, stud spacing and so on. So it is difficult to be determined only by theoretical calculation, and the available researches have been carried out mainly by test method (AISI [2], Serrette and Ogunfunmi [3], and Serrette et al. [4]). However, tests can not totally reflect the influence of all the factors on the shear resistance of walls. Finite element (FE) method validated by test is an effective method to study it (Xia and Dong [5], Emad et al. [6]). Many scholars have only studied the shear resistance for a certain kind of cold-formed steel stud walls because of the complex factors mentioned above. In order to provide design guidelines, tests and FE analyses are carried out to study the shear resistance of the cold-formed steel stud walls in residential structures, and many influencing factors are also analyzed in this paper.

\section{TEST PROGRAM}

\subsection{Details of Specimens}

The configurations of specimens are described in Table 1 , and the walls with size of $3 \mathrm{~m} \times 2.4 \mathrm{~m}$ (height by wide) and $1.0 \mathrm{~mm}$ thick steel framing are sheathed with gypsum or OSB sheathing. But 
there is a vertical connecting seam on the wall because every board is only half the width of the wall, and there is a horizontal connecting seam on the wall sheathed with OSB because the length of the OSB sheathing is shorter than that of the wall, so a steel strap with $50 \mathrm{~mm}$ wide and $1.0 \mathrm{~mm}$ thick is fixed along the horizontal connecting seam to strengthen the wall. The studs in the middle of the wall are single $\mathrm{C}$-shaped cold-formed steel members, and the studs at both ends of the wall are two back-to-back C-shaped members connected by two lines of self-drilling screws. The $16 \mathrm{~mm}$ diameter uplift anchors are used to connect the walls to the test beam at the corner of the wall, and the top and bottom tracks of the wall are fixed to the test beam by $12 \mathrm{~mm}$ diameter shear anchors. The yield strength of steel $f_{y}$ is $320 \mathrm{~N} / \mathrm{mm}^{2}$, the ultimate tensile strength $f_{u}$ is $379 \mathrm{~N} / \mathrm{mm}^{2}$, and the extension percentage of steel is $34 \%$. The configuration of the DSGO wall (wall with gypsum sheathing on the back and oriented strand board on the front) is displayed in Figure 1.

Table 1. Specimens of Shear Wall Tests

\begin{tabular}{|c|c|c|c|c|}
\hline $\begin{array}{l}\text { Denotation } \\
\text { of wall } \\
\text { specimens }\end{array}$ & Sheathing & $\begin{array}{l}\text { Self-drilling } \\
\text { fastener }\end{array}$ & $\begin{array}{c}\text { Fastener } \\
\text { spacing }\end{array}$ & Cold-formed steel member \\
\hline SSG & $\begin{array}{l}\text { gypsum board on one side, } \\
\text { with dimensions of } 1.2 \mathrm{~m} \times 3 \mathrm{~m} \\
\text { and thickness of } 12 \mathrm{~mm}\end{array}$ & ST4.2 & \multirow{3}{*}{$\begin{array}{l}150 \mathrm{~mm} \text { at } \\
\text { the } \\
\text { perimeter } \\
\text { and } 300 \mathrm{~mm} \\
\text { in the } \\
\text { middle field } \\
\text { of board }\end{array}$} & \multirow{3}{*}{$\begin{array}{c}\text { C } 89 \times 44.5 \times 12 \times 1.0 \text { studs (lipped } \\
\text { channel section with web height } \\
89 \mathrm{~mm} \text {, flange width } 44.5 \mathrm{~mm} \text {, } \\
\text { lip width } 12 \mathrm{~mm} \text { and thickness } \\
1 \mathrm{~mm} \text { ), Spaced } 600 \mathrm{~mm} \text { on center } \\
\text { U92 } \times 40 \times 1.0 \text { tracks (channel } \\
\text { section with web height } 91 \mathrm{~mm} \text {, } \\
\text { flange width } 40 \mathrm{~mm} \text { and } \\
\text { thickness } 1 \mathrm{~mm} \text { ) } \\
50 \mathrm{~mm} \times 1.0 \mathrm{~mm} \text { strap }\end{array}$} \\
\hline SSO & $\begin{array}{l}\text { OSB on one side, with } \\
\text { dimensions of } 1.2 \mathrm{~m} \times 2.44 \mathrm{~m} \\
\text { and thickness of } 9 \mathrm{~mm}\end{array}$ & ST4.8 & & \\
\hline DSGO & $\begin{array}{l}\text { gypsum board with thickness } \\
\text { of } 12 \mathrm{~mm} \text { on one side and } \\
\text { OSB with thickness of } 9 \mathrm{~mm} \\
\text { on the other side }\end{array}$ & $\begin{array}{l}\text { ST4.2 and } \\
\text { ST4.8 }\end{array}$ & & \\
\hline
\end{tabular}

\subsection{Test Apparatus}

The test apparatus are shown in Figure 2. The horizontal load is applied to the wall through electro-hydraulic servo actuator, and the lateral braces are also provided to limit out-of-plane movement of the test wall. The test process is operated by M2801 servo-control mechanism and computer. All the test data are collected by 7V08 date collector.

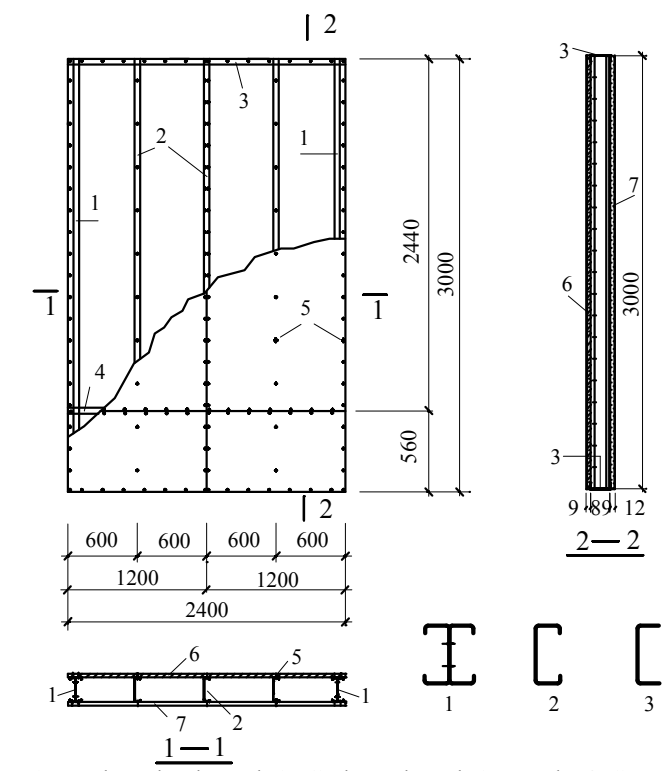

1. Back-to-back stud; 2. C-shaped stud; 3. Track; 4. Strap; 5. Self-drilling fastener; 6. Gypsum sheathing; 7. OSB sheathing Figure 1. Configuration of the DSGO Wall

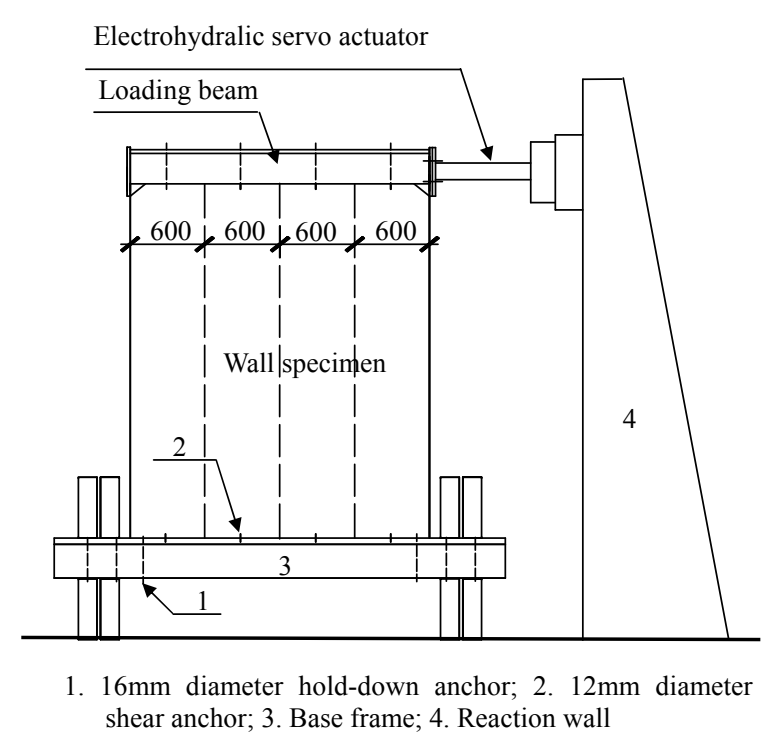

Figure 2. Test Apparatus 


\subsection{Loading Process and Failure Characteristics of the Specimens}

The specimens are loaded to yield period by controlling 5 7 loading steps. After yielding, the specimens are loaded to failure by controlling displacement steps. And the duration of each loading stage is about 3 minutes. It is found that the shear resistance and stiffness of the SSG (single-sided gypsum sheathing) specimen are lower. As a result, the relative rotation occurs between the two panels of gypsum sheathings, and their vertical connecting seams offset. The gypsum sheathing is torn at the corner of the wall (as shown in Figure 3(a)). The shear resistance strength and ductility of the SSO wall (wall with single-sided oriented strand board sheathing) are better than those of the SSG wall, but the horizontal connecting seam in the SSO wall has influence on its bearing capacity and stiffness. With increase of the load, the buckling of the steel strap occurs apparently (as shown in Figure 3(b)), and the slip of the four panels of OSB sheathing is relatively great (as shown in Figure 3(c)), which makes the shear stiffness of the wall reduced. The integrity, strength, and stiffness of the DSGO wall remarkably excel those of the SSG wall and SSO wall. But the failure modes of three kinds of walls are similar. In general, when the failure of all the wall specimens occur under the shear load, most of the screw connecting sheathing and steel members around the wall fail, and local buckling of the stud on the end of the wall takes place (as shown in Figure 3(d)). But the gypsum sheathing or OSB sheathing does not drop off integrally due to the less damage of the screw connections in the middle field of the wall, so we can conclude that the screws at the perimeter bear higher shear load than those in the middle field.

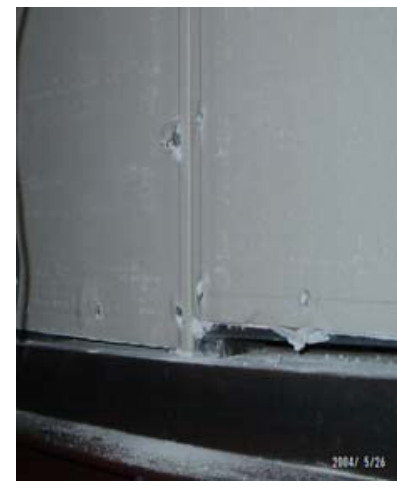

(a)

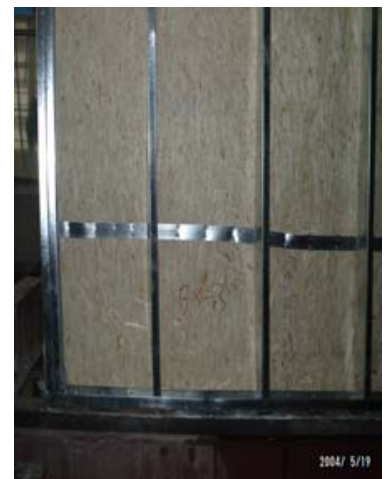

(b)

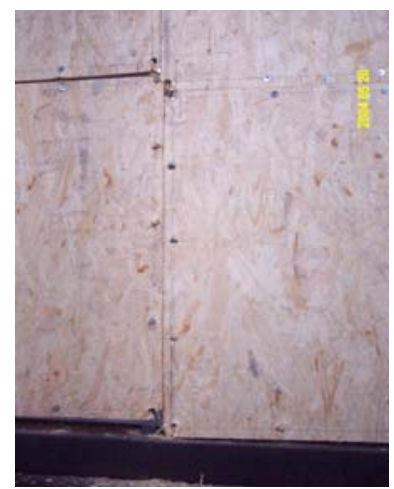

(c)

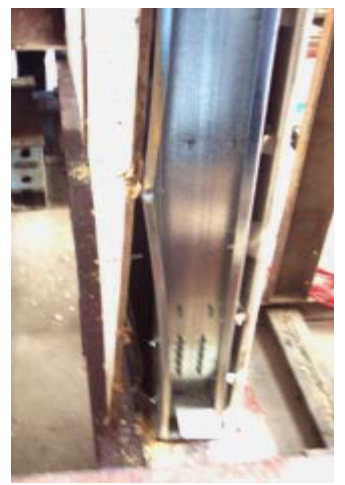

(d)

Figure 3. Failure Modes of Specimens:

(a) Gypsum Sheathing Tearing at Corner of Wall; (b) Buckling of Strap;

(c) Slip of Four Panels of OSB Sheathing; (d) Local Buckling of Studs

\section{$2.4 \quad$ Analysis of the Test Results}

The shear load-displacement $(P-\Delta)$ curves of all the wall specimens are showed in Figure 4 . The yield load of all the walls can not been easily found from these curves, so all the characteristic loads including yield load are determined by the method prescribed in Chinese Specification of Testing Methods for Earthquake Resistant Building (JGJ 101-96 [7]). The method for determining the characteristic loads of the wall is illustrated in Figure 5. Horizontal Line AB is drawn form the point A defining maximum load $P_{\max }$, then secant $\mathrm{OD}$ is drawn intersecting line $\mathrm{AB}$ and curve $\mathrm{OA}$ at point $\mathrm{D}$ and $\mathrm{C}$ respectively on condition that the area $\mathrm{ADCA}$ is equal to the area CFOC. A vertical line is drawn form point $\mathrm{D}$ intersecting curve $\mathrm{OA}$ at point $\mathrm{E}$. The shear load and the corresponding displacement of point E are the yield load $P_{y}$ and the yield displacement $\Delta_{y}$ of the wall, respectively. After the maximum value, the load will descend with the increase of the displacement, and when it descends to $0.85 P_{\max }$, the corresponding load and displacement are 
defined as the failure load $P_{u}$ and displacement $\Delta_{u}$, respectively. The test results determined by the method described above are listed in Table 2.

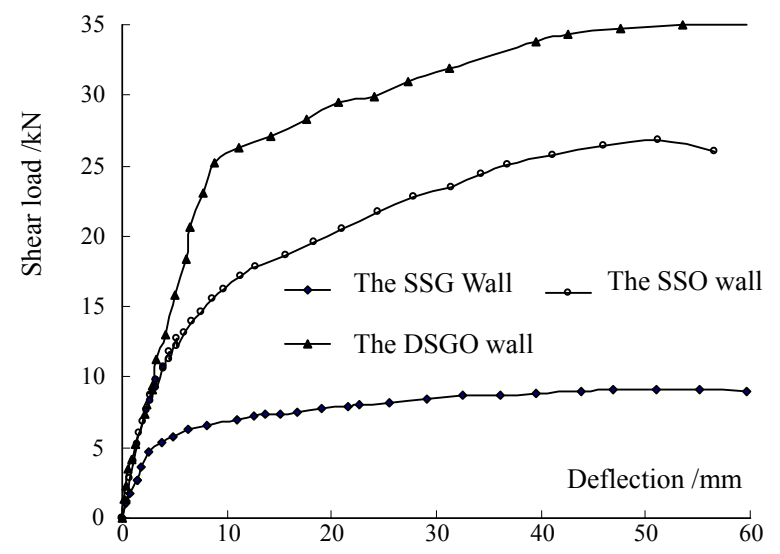

Figure 4. Load Displacement Curves of the Specimens

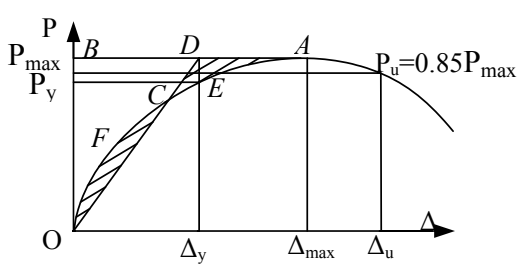

Figure 5. Determination for Special Load Points of the Specimens

Table 2. Experimental Results

\begin{tabular}{cccccccc}
\hline $\begin{array}{c}\text { Wall } \\
\text { type }\end{array}$ & $\mathrm{P}_{\mathrm{y}}(\mathrm{kN})$ & $\begin{array}{c}\Delta_{\mathrm{y}} \\
(\mathrm{mm})\end{array}$ & $\begin{array}{c}\mathrm{P}_{\max } \\
(\mathrm{kN})\end{array}$ & $\begin{array}{c}\Delta_{\max } \\
(\mathrm{mm})\end{array}$ & $\mathrm{P}_{\mathrm{u}}(\mathrm{kN})$ & $\begin{array}{c}\Delta_{\mathrm{u}} \\
(\mathrm{mm})\end{array}$ & $\begin{array}{c}\text { Shear } \\
\text { resistance } \\
(\mathrm{kN} / \mathrm{m})\end{array}$ \\
\hline $\mathrm{SSG}$ & 7.48 & 13.5 & 9.12 & 48 & 7.75 & 74.8 & 3.8 \\
$\mathrm{SSO}$ & 21.5 & 23.9 & 26.84 & 51.21 & 22.81 & 68 & 11.18 \\
$\mathrm{DSGO}$ & 29.12 & 19.6 & 34.99 & 59.62 & 29.72 & 74 & 14.58 \\
\hline
\end{tabular}

It is found from the table that, the yield load $P_{y}$, maximum load $P_{\max }$, and failure load $P_{u}$ of the SSO wall are approximately 2.87, 2.94, and 2.94 times those of the SSG wall under the monotonic loading. That is, the load bearing capacity of the wall with single-sided gypsum sheathing is $34 \sim 34.8 \%$ that of the wall with single-sided OSB sheathing.

The sum of the yield loads of the SSG and SSO walls is $28.98 \mathrm{kN}$, sum of the maximum loads of those two kinds of walls is $35.96 \mathrm{kN}$, and that of the failure loads of them is $30.56 \mathrm{kN}$, which are close to the corresponding yield load $29.12 \mathrm{kN}$, maximum load $34.99 \mathrm{kN}$, and failure load $29.72 \mathrm{kN}$ of the DSGO wall, respectively. This indicates that the total load bearing capacity of the two kinds of single-sided walls is close to that of the double-faced wall with the two corresponding kinds of sheathings.

\section{FE ANALYSIS}

\subsection{FE Analysis Model}

FE model is a mathematic representation of the practical structure, and it should reflect the main performance of every member. The equilibrium equation of the wall is given by

$[K]\{\delta\}=[P]$ 
where $[P]$ and $\{\delta\}$ are the nodal displacement and load vectors, respectively; $[K]=\int_{V}[B]^{\mathrm{T}}[D][B] d V$ is the structural stiffness matrix, $[B]$ and $[D]$ denote the geometric and material constitutive matrices, respectively, and $V$ represents the structural volume. In addition,

$$
\begin{aligned}
& \{\sigma\}=[D]\{\varepsilon\} \\
& \{\varepsilon\}=[B]\{\delta\}
\end{aligned}
$$

in which $\{\sigma\}$ and $\{\varepsilon\}$ are the stress and stain matrices, respectively.

Since the geometrical and materials nonlinearities are considered in the equilibrium equation, the both matrices $[B]$ and $[D]$ are related to the stress or strain, the structural stiffness matrix $[K]$ is therefore not constant in the process of gradually loading.

The FE analysis software ANSYS (ANSYS version 10.0 [8]) is adopted to analyze the wall specimens under the monotonic load. The plastic shell element 'Shell181' is used to simulate the cold-formed steel members and sheathing panels, and the material properties referring to the References (Kasal and Leichti [9], Thomas [10], Zhou and He [11]) are listed in Table 3. The screw

Table 3. Material Properties of Specimen

\begin{tabular}{cccc}
\hline Material & $\begin{array}{c}\text { Young's modulus } \\
\left(\mathrm{N} / \mathrm{mm}^{2}\right)\end{array}$ & $\begin{array}{c}\text { Tensile strength } \\
\left(\mathrm{N} / \mathrm{mm}^{2}\right)\end{array}$ & Poisson's ratio \\
\hline Gypsum board & 1124.7 & 0.66 & 0.23 \\
OSB & 3500 & 7.86 & 0.3 \\
Steel & $2.06 \mathrm{e} 5$ & 320 & 0.3 \\
\hline
\end{tabular}

connections are handled by coupling method, and the screws are assumed to have free rotations but no displacements along $\mathrm{X}-, \mathrm{Y}$-, and $\mathrm{Z}$-directions without considering the slip between the sheathing and the steel members. The studs and tracks are simply connected. The displacements of the bottom track along $X$-, $Y$-, as well as $Z$-directions and rotations along $Y$ - and $Z$-directions are restrained, that

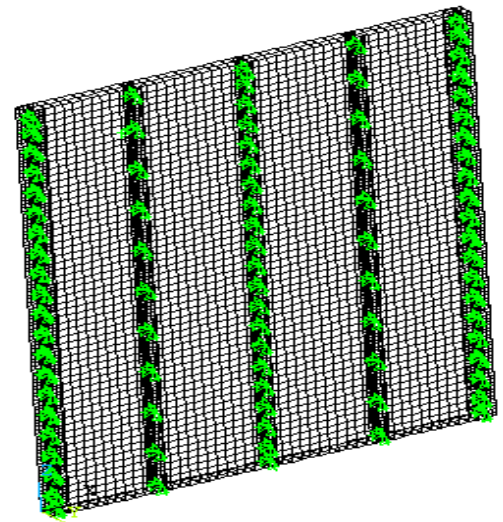

Figure 6. FE Model of Wall 
is, $U_{X}=0, U_{Y}=0, U_{Z}=0, \theta_{Y}=0$, and $\theta_{Z}=0$. Additionally, the top track is assumed to have no displacement and rotation along $Y$ - and $Z$-directions, i.e., $U_{Y}=0, U_{Z}=0, \theta_{Y}=0$, and $\theta_{Z}=0$. The FE model is shown in Figure 6, in which the nodes of top track are coupled in $X$-direction and the displacement corresponding to the maximum load is applied on the coupled nodes. The loading process is also controlled by displacement.

\subsection{Analyses of the Specimens}

To verify the validity of the above-mentioned FE method, the test specimens of the SSG, SSO and SSGO walls described in Section 2 are analyzed first, and the analytical results are displayed in Figures 7-9. It is found that, when the horizontal monotonic load is applied to the top point $c$, the side $a c$ of the walls is in tension while the side $b d$ is in compression, and the walls slope. In addition, the sheathing is mainly damaged in the screw connections at both the top and the bottom of the walls, and local buckling occurs at the top and bottom ends of the compressed back-to-back studs, even the overall buckling of the stud No. 4 in the single-sided wall. But the studs in the double-faced wall have lighter distortion than those in the single-sided wall, since the double-faced sheathing can constrain the steel frame more effectively than the single-sided sheathing.

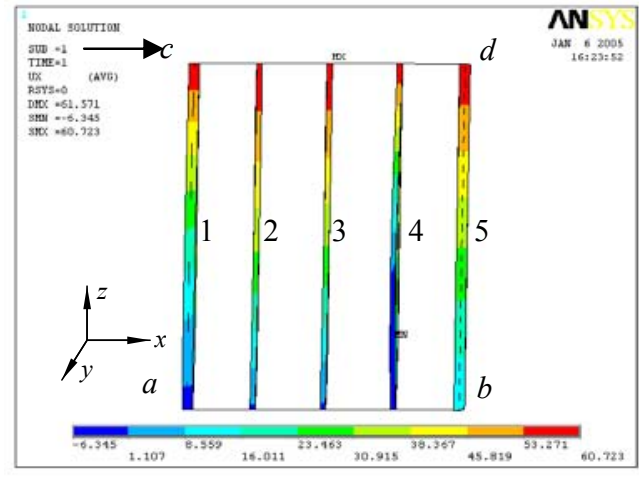

(a)

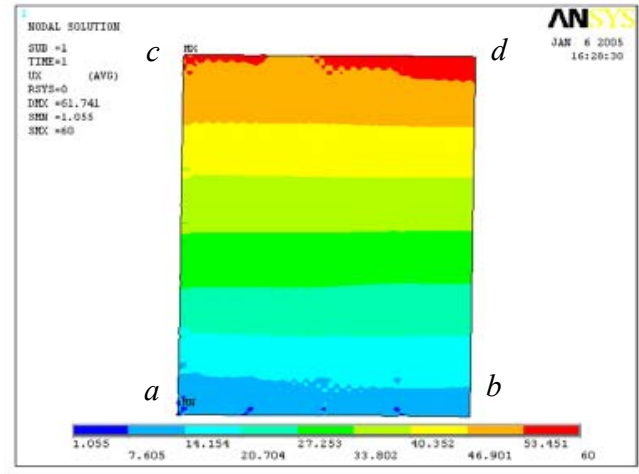

(b)

Figure 7. Displacement of the SSG Wall: (a) Displacement along X-direction of Steel Framing Gypsum; (b) Displacement along X-direction of Sheathing

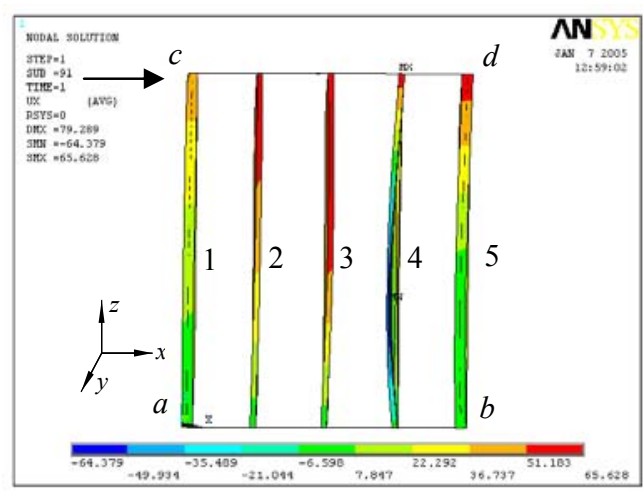

(a)

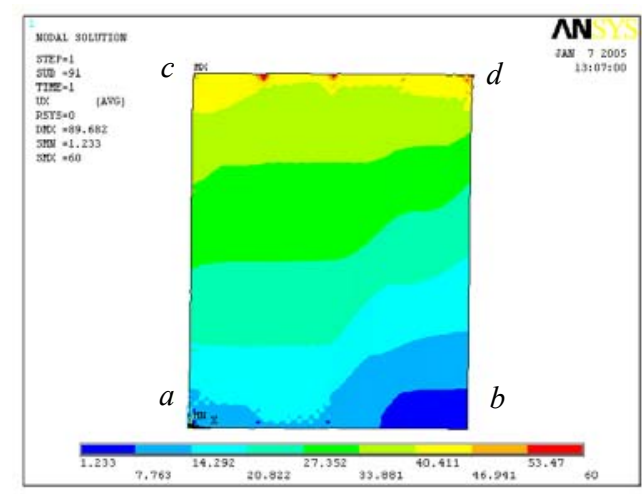

(b)

Figure 8. Displacement of the SSO Wall: (a) Displacement along X-Direction of Steel Framing; (b) Displacement along X-Direction of OSB 


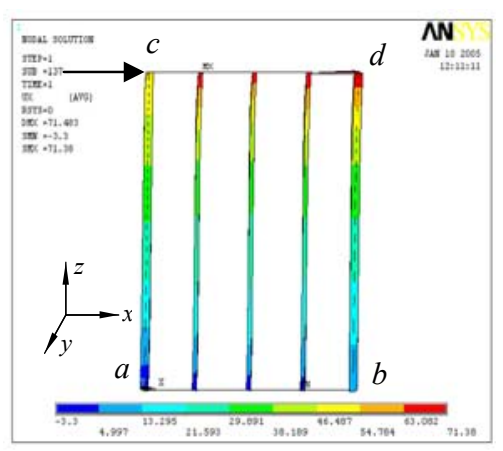

(a)

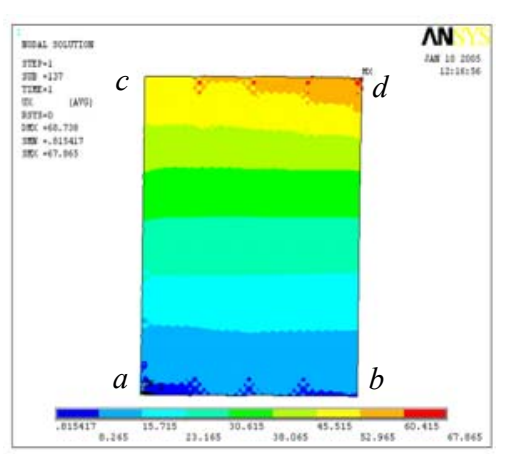

(b)

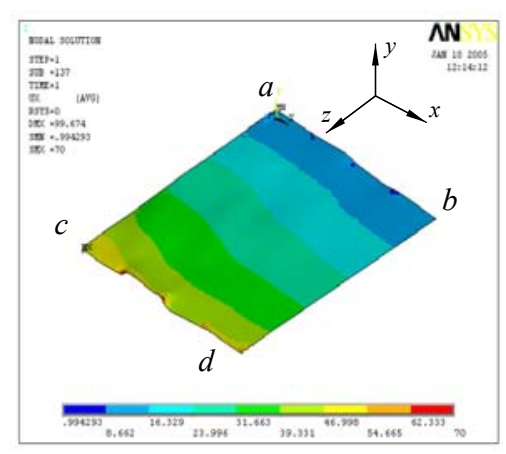

(c)

Figure 9. Displacement of the DSGO Wall: (a) Displacement along X-Direction of Steel Framing; (b) Displacement along X-Direction of Gypsum Sheathing; (c) Displacement along X-Direction of OSB

From the comparison of the load-displacement curves as shown in Figure 10, it can be seen that the results by FE analysis are very close to those by test. Since there are not obvious characteristic points in the load-displacement curves, they are determined according to the methods suggested in Chinese Specification of Testing Methods for Earthquake Resistant Building (JGJ 101-96 [7]). And the result comparisons between the test and FE analysis are shown in Table 4.

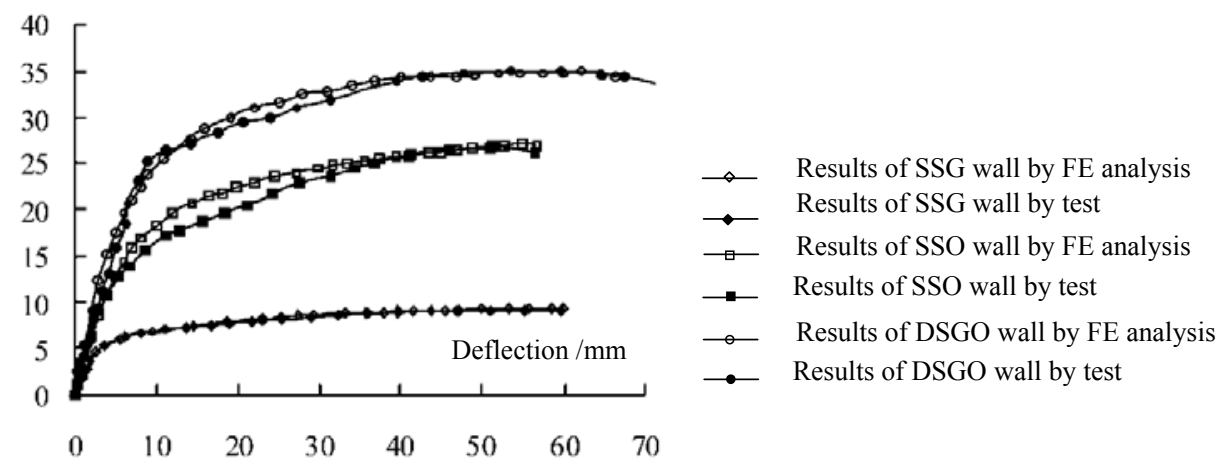

Figure 10. Comparison of the Results between Test and FE Analysis

Table 4. The Results of Test and FE Analyses

\begin{tabular}{ccccccc}
\hline Wall type & Items & $\begin{array}{c}\mathrm{P}_{\mathrm{y}} \\
(\mathrm{kN})\end{array}$ & $\begin{array}{c}\Delta_{\mathrm{y}} \\
(\mathrm{mm})\end{array}$ & $\begin{array}{c}\mathrm{P}_{\max } \\
(\mathrm{kN})\end{array}$ & $\begin{array}{c}\Delta_{\max } \\
(\mathrm{mm})\end{array}$ & $\begin{array}{c}\text { Shear } \\
\text { resistance } \\
(\mathrm{kN} / \mathrm{m})\end{array}$ \\
\hline \multirow{2}{*}{ SSG } & Test & 7.48 & 13.5 & 9.12 & 48 & 3.8 \\
& FE analysis & 7.71 & 16.59 & 9.29 & 59.79 & 3.87 \\
\multirow{2}{*}{ SSO } & Test & 21.5 & 23.9 & 26.84 & 51.21 & 11.18 \\
& FE analysis & 22.46 & 20.33 & 26.98 & 55.15 & 11.24 \\
& Test & 29.12 & 19.6 & 34.99 & 59.62 & 14.58 \\
& FE analysis & 29.73 & 17.92 & 34.86 & 60.11 & 14.52 \\
\hline
\end{tabular}

The displacements of the walls related to the yield point and maximum load point measured by test differ somewhat from those obtained by FE analysis, and the maximum error reaches to $24.56 \%$. But the errors of shear load bearing capacities of the SSG, SSO, and DSGO walls are only $0.34 \%$ to $1.84 \%$, and those of yield loads of these three kinds of walls are only $2.1 \%$ to $6.03 \%$. So the results 
by FE analysis are very consistent with those by test. Especially, the shear resistance of the SSO wall obtained by FE analysis is $11.24 \mathrm{kN} / \mathrm{m}$, which is only $3.1 \%$ lower than that of the wall with the same configuration presented in Reference (The Japan Iron and Steel Federation [12]). This indicates that the method of FE analysis adopted in this paper is correct and valid.

\subsection{Parametric Analyses}

Based on the FE method, a series of parametric analyses on the SSG, SSO, and DSGO walls are carried out in this section to study the influence of the steel strength, stud spacing, stud height, and screw spacing on the shear load bearing capacity of the walls.

\subsubsection{Influence of the steel strength on the shear resistance of wall}

The yield strength of steel in the wall with single-sided gypsum sheathing is $320 \mathrm{~N} / \mathrm{mm}^{2}$, and the maximum resistance of the wall is $9.29 \mathrm{kN}$. But when the steel yield strength of this wall is changed to $205 \mathrm{~N} / \mathrm{mm}^{2}$, the maximum resistance calculated by FE method is $8.95 \mathrm{kN}$, which is only $3.65 \%$ lower than that of the former. For more clarity, the load-displacement curves of those two kinds of walls are showed in Figure 11. Obviously, the change of steel strength has little influence on the shear resistance of the wall.

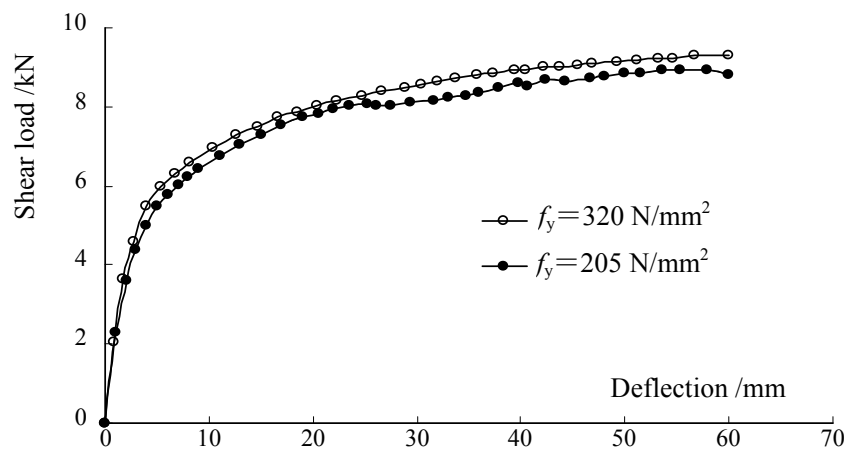

Figure 11. Load-Displacement Curves of the SSG Walls with Different

\subsubsection{Influence of the studs spacing on the shear resistance}

The studs of cold-formed steel stud walls usually space $400 \mathrm{~mm}$ and $600 \mathrm{~mm}$. However, stud spacing of the test specimens and the FE models described above is $600 \mathrm{~mm}$. Now the stud spacing of the SSG, SSO, and the DSGO walls is adjusted as $400 \mathrm{~mm}$, and the FE analytical results of these walls are listed in Table 5, and the load-displacement curves are showed in Figure 12. It can be seen that, when the stud spacing reduce from $600 \mathrm{~mm}$ to $400 \mathrm{~mm}$, the shear resistances of the SSG, SSO, and the DSGO walls increase by $14.47 \%, 24.11 \%$, and $29.96 \%$, respectively. Therefore, the stud spacing has remarkable influence on the shear load bearing capacity of the cold-formed steel stud walls, and this influence is strengthened with increase of the sheathing restriction.

Table 5. FE Analysis Results of the Walls

\begin{tabular}{cccc}
\hline Wall type & Stud spacing $(\mathrm{mm})$ & $\mathrm{P}_{\max }(\mathrm{kN})$ & $\begin{array}{c}\text { Shear resistance } \\
(\mathrm{kN} / \mathrm{m})\end{array}$ \\
\hline \multirow{2}{*}{ SSG } & 400 & 10.62 & 4.43 \\
& 600 & 9.29 & 3.87 \\
SSO & 400 & 33.47 & 13.95 \\
& 600 & 26.98 & 11.24 \\
\multirow{2}{*}{ DSGO } & 400 & 45.29 & 18.87 \\
& 600 & 34.84 & 14.52 \\
\hline
\end{tabular}




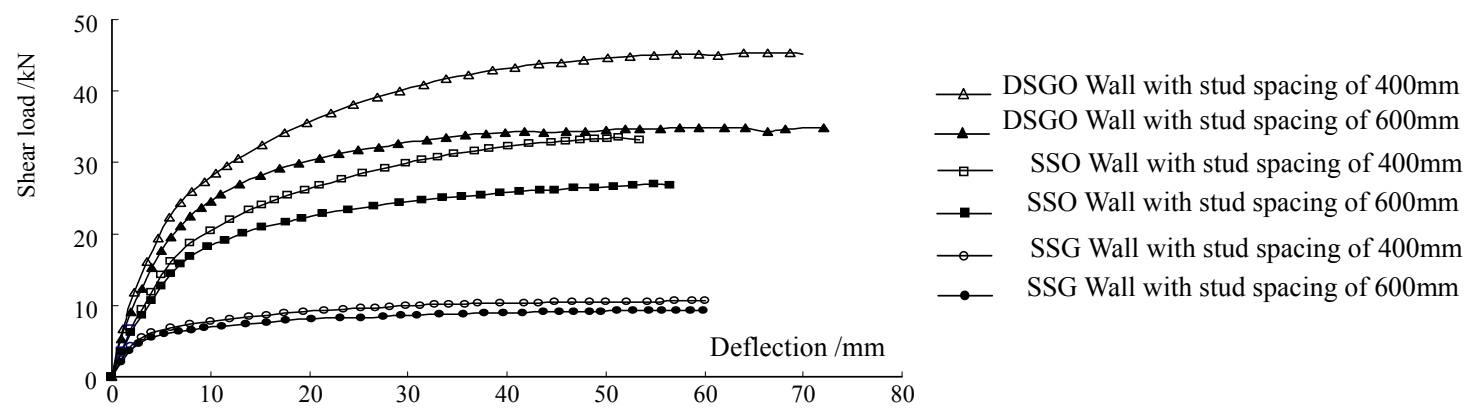

Figure 12. Load-displacement Curves of Cold-formed Steel Stud Walls with Different Stud Spacing

\subsubsection{Influence of the height-width ratio of wall on the shear resistance}

To investigate the influence of the height-width ratio of wall on the shear resistance, three walls with single-sided gypsum sheathing are analyzed by FE method, in which the widths of the walls are all $2.4 \mathrm{~m}$ and the heights are $2.4 \mathrm{~m}, 2.7 \mathrm{~m}$, and $3 \mathrm{~m}$, respectively. The analytical results are listed in Table 6, and the load-displacement curves are showed in Figure 13.

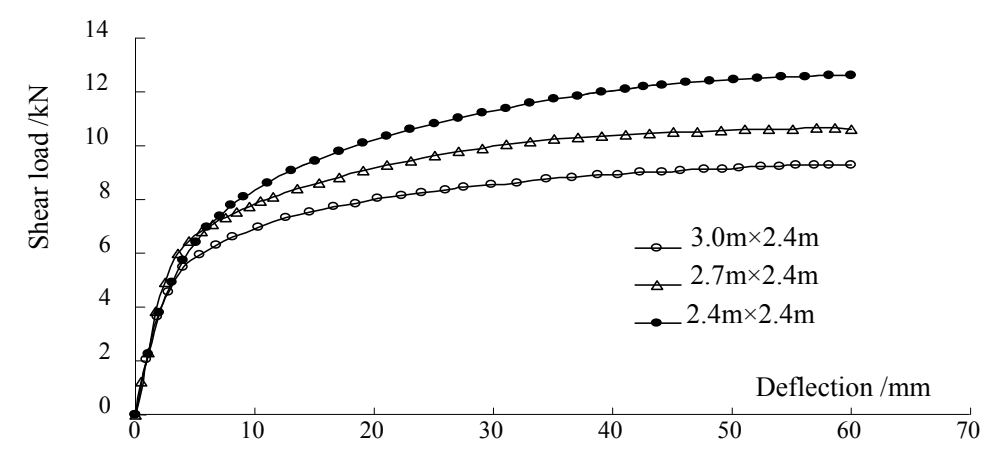

Figure 13. Load-displacement Curves of SSG Walls with Different Dimensions

Table 6. FE Analysis Results of the SSG Wall with Different Height-width Ratios

\begin{tabular}{cccc}
\hline $\begin{array}{c}\text { Dimension of walls } \\
(\text { height } \times \text { width })\end{array}$ & Height-width ratio & $\mathrm{P}_{\max }(\mathrm{kN})$ & $\begin{array}{c}\text { Shear resistance } \\
(\mathrm{kN} / \mathrm{m})\end{array}$ \\
\hline $2.4 \mathrm{~m} \times 2.4 \mathrm{~m}$ & $1: 1$ & 12.63 & 5.26 \\
$2.7 \mathrm{~m} \times 2.4 \mathrm{~m}$ & $1.125: 1$ & 10.63 & 4.44 \\
$3.0 \mathrm{~m} \times 2.4 \mathrm{~m}$ & $1.250: 1$ & 9.29 & 3.87 \\
\hline
\end{tabular}

It is found that, the shear resistance of the wall with dimensions of $3 \mathrm{~m} \times 2.4 \mathrm{~m}$ is $12.84 \%$ lower than that of wall with dimensions of $2.7 \mathrm{~m} \times 2.4 \mathrm{~m}$, whose shear resistance is then $15.59 \%$ lower than that of wall with dimensions of $2.4 \mathrm{~m} \times 2.4 \mathrm{~m}$. So the shear resistance of the wall will decrease with increase of the height-width ratio, the height-width ratio of the wall has large influence on the shear load bearing capacity.

\subsubsection{Influence of the screw spacing on the shear resistance}

Similarly, to investigate the influence of the screw spacing on the shear resistance of wall, the SSG, SSO, and the DSGO walls with different screw spacing are analyzed by FE method, and analytical results are listed in Table 7. 
Table 7. FE Analysis Results of the Walls with Different Screw Spacing

\begin{tabular}{cccc}
\hline Wall type & Screw spacing $(\mathrm{mm})$ & $\mathrm{P}_{\max }(\mathrm{kN})$ & Shear resistance $(\mathrm{kN} / \mathrm{m})$ \\
\hline \multirow{3}{*}{$\mathrm{SSG}$} & $100 / 300$ & 9.93 & 4.14 \\
& $150 / 300$ & 9.29 & 3.87 \\
& $150 / 150$ & 9.60 & 4 \\
\hline \multirow{3}{*}{$\mathrm{SSO}$} & $100 / 300$ & 27.34 & 11.39 \\
& $150 / 300$ & 26.98 & 11.24 \\
& $150 / 150$ & 27.74 & 11.56 \\
\hline \multirow{2}{*}{ DSGO } & $100 / 300$ & 38.52 & 16.05 \\
& $150 / 300$ & 34.84 & 14.52 \\
& $150 / 150$ & 35.53 & 14.80 \\
\hline
\end{tabular}

It is found that, the shear resistances of the walls increase with decrease of the screw spacing. When the screw spacing of these three kinds of walls, is adjusted from 150/150 (the screw spacing at the perimeter / that in the middle field of the wallboard) to 150/300, their shear resistance will increase by $3.36 \%, 2.85 \%$, and $1.93 \%$, respectively. And if the screw spacing is changed as $100 / 300$, the corresponding shear resistances of these three kinds of walls will respectively increase by $6.98 \%, 1.33 \%$, and $10.54 \%$, comparing with the walls with screw spacing of $150 / 300$. So we can conclude that, when the screw spacing is less than $300 \mathrm{~mm}$, the decrease of the screw spacing in the middle field has not remarkable influence on the shear resistance of the wall, but the shear resistance will be effectively strengthened with decrease of the screw spacing at the perimeter. This is consistent with the phenomenon observed in the test.

\subsection{Design Suggestions}

To guide actual engineering design, a great number of cold-formed steel stud walls with different values of parameters are further analyzed by FE method combined with test introduced in this paper. And the recommended shear resistances of the walls are presented in Table 8 , in which, the steel yield strength is $300 \mathrm{~N} / \mathrm{mm}^{2}$, sections of the studs and tracks are $\mathrm{C} 89 \times 44.5 \times 12 \times 1$ and $\mathrm{U} 92 \times 40 \times 1$, respectively.

Table 8. The Shear Resistances of Cold-formed Steel Stud Walls with Different Parameters

\begin{tabular}{|c|c|c|c|c|}
\hline $\begin{array}{c}\text { Dimension of wall } \\
\text { (height } \times \text { width) } \\
(\mathrm{m})\end{array}$ & $\begin{array}{c}\text { Stud } \\
\text { spacing } \\
(\mathrm{mm})\end{array}$ & $\begin{array}{l}\text { Screw } \\
\text { spacing } \\
(\mathrm{mm})\end{array}$ & Sheathing & $\begin{array}{c}\text { Shear } \\
\text { resistance } \\
(\mathrm{kN} / \mathrm{m})\end{array}$ \\
\hline \multirow[t]{14}{*}{$3 \times 2.4$} & \multirow{14}{*}{600} & \multirow{7}{*}{$150 / 300$} & $12 \mathrm{~mm}$ thick gypsum board on one side & 3.87 \\
\hline & & & 9mm thick OSB on one side & 11.24 \\
\hline & & & $12 \mathrm{~mm}$ thick OSB on one side & 13.48 \\
\hline & & & $\begin{array}{l}12 \mathrm{~mm} \text { thick gypsum board on one side and } 9 \mathrm{~mm} \\
\text { thick OSB on the other side }\end{array}$ & 14.52 \\
\hline & & & $12 \mathrm{~mm}$ thick gypsum board on both sides & 7.31 \\
\hline & & & $12 \mathrm{~mm}$ thick OSB on both sides & 25.1 \\
\hline & & & $\begin{array}{l}12 \mathrm{~mm} \text { thick gypsum board on one side and } 12 \mathrm{~mm} \\
\text { thick OSB on the other side }\end{array}$ & 17.11 \\
\hline & & \multirow{7}{*}{$100 / 300$} & $12 \mathrm{~mm}$ thick gypsum board on one side & 4.14 \\
\hline & & & $9 \mathrm{~mm}$ thick OSB on one side & 12.54 \\
\hline & & & $12 \mathrm{~mm}$ thick OSB on one side & 15.01 \\
\hline & & & $\begin{array}{l}12 \mathrm{~mm} \text { thick gypsum board on one side and } 9 \mathrm{~mm} \\
\text { thick OSB on the other side }\end{array}$ & 15.89 \\
\hline & & & $12 \mathrm{~mm}$ thick gypsum board on both sides & 7.94 \\
\hline & & & $12 \mathrm{~mm}$ thick OSB on both sides & 25.12 \\
\hline & & & $\begin{array}{l}12 \mathrm{~mm} \text { thick gypsum board on one side and } 12 \mathrm{~mm} \\
\text { thick OSB on the other side }\end{array}$ & 18.45 \\
\hline
\end{tabular}




\begin{tabular}{|c|c|c|c|c|}
\hline & \multirow{14}{*}{400} & \multirow{7}{*}{$150 / 300$} & $12 \mathrm{~mm}$ thick gypsum board on one side & 4.43 \\
\hline & & & 9mm thick OSB on one side & 13.95 \\
\hline & & & $12 \mathrm{~mm}$ thick OSB on one side & 21.26 \\
\hline & & & $\begin{array}{l}12 \mathrm{~mm} \text { thick gypsum board on one side and } 9 \mathrm{~mm} \\
\text { thick OSB on the other side }\end{array}$ & 18.87 \\
\hline & & & $12 \mathrm{~mm}$ thick gypsum board on both sides & 8.26 \\
\hline & & & $12 \mathrm{~mm}$ thick OSB on both sides & 42.72 \\
\hline & & & $\begin{array}{l}12 \mathrm{~mm} \text { thick gypsum board on one side and } 12 \mathrm{~mm} \\
\text { thick OSB on the other side }\end{array}$ & 27.85 \\
\hline & & & $12 \mathrm{~mm}$ thick gypsum board on one side & 4.82 \\
\hline & & & 9mm thick OSB on one side & 15.75 \\
\hline & & & $12 \mathrm{~mm}$ thick OSB on one side & 21.98 \\
\hline & & $100 / 300$ & $\begin{array}{l}12 \mathrm{~mm} \text { thick gypsum board on one side and } 9 \mathrm{~mm} \\
\text { thick OSB on the other side }\end{array}$ & 20.57 \\
\hline & & & $12 \mathrm{~mm}$ thick gypsum board on both sides & 8.32 \\
\hline & & & $12 \mathrm{~mm}$ thick OSB on both sides & 38.84 \\
\hline & & & $\begin{array}{l}12 \mathrm{~mm} \text { thick gypsum board on one side and } 12 \mathrm{~mm} \\
\text { thick OSB on the other side }\end{array}$ & 27.87 \\
\hline \multirow{6}{*}{$2.7 \times 2.4$} & \multirow{6}{*}{600} & \multirow{3}{*}{$150 / 300$} & $12 \mathrm{~mm}$ thick gypsum board on one side & 3.91 \\
\hline & & & $9 \mathrm{~mm}$ thick OSB on one side & 12.08 \\
\hline & & & $12 \mathrm{~mm}$ thick OSB on one side & 14.30 \\
\hline & & \multirow{3}{*}{$100 / 300$} & $12 \mathrm{~mm}$ thick gypsum board on one side & 4.24 \\
\hline & & & $9 \mathrm{~mm}$ thick OSB on one side & 12.92 \\
\hline & & & $12 \mathrm{~mm}$ thick OSB on one side & 14.67 \\
\hline \multirow{6}{*}{$2.4 \times 2.4$} & \multirow{6}{*}{600} & \multirow{3}{*}{$150 / 300$} & $12 \mathrm{~mm}$ thick gypsum board on one side & 4.97 \\
\hline & & & 9mm thick OSB on one side & 13.70 \\
\hline & & & $12 \mathrm{~mm}$ thick OSB on one side & 16.51 \\
\hline & & \multirow{3}{*}{$100 / 300$} & $12 \mathrm{~mm}$ thick gypsum board on one side & 5.29 \\
\hline & & & $9 \mathrm{~mm}$ thick OSB on one side & 14.33 \\
\hline & & & $12 \mathrm{~mm}$ thick OSB on one side & 18.23 \\
\hline
\end{tabular}

\section{CONCLUSIONS}

The shear resistances of cold-formed steel stud assembled walls in residential structures are investigated in this paper. By experiment and FE analyses, some conclusions are drawn as follows.

(1) The FE analytical results are close to the experimental results, which indicates that the method of FE analysis adopted in this paper is correct and valid.

(2) The material properties of the panel sheathing influence the shear load bearing capacity of the cold-formed steel stud wall greatly. The shear resistance of the wall with single-sided gypsum sheathing is 34.8 percent of that of the wall with single-sided OSB sheathing, and the total shear resistance of these two kinds of single-sided walls is close to that of the double-faced wall with gypsum board on one side and OSB on the other side.

(3) The shear resistance of the walls increases obviously with decrease of the stud spacing and the screw spacing at the perimeter of the walls, and it also increases with decrease of the height-width ratio of the walls. However, the influence of the steel strength on the shear resistance is not remarkable, though it will be enhanced with increase of the steel strength. 


\section{ACKNOWLEDGEMENT}

This work was financially supported by the National Natural Science Foundation of China (Grant No. 50578013), Program for New Century Excellent Talents in University (Grant No. NCET-07-0266), Natural Science Foundation of Hunan Province for Distinguished Young Scholars (Grant No. 08JJ1006), and National Key Technology R\&D Program (Grant No. 2006BAJ18B06-01), which are gratefully acknowledged.

\section{REFERENCES}

[1] NASFA, "Prescriptive Method for Residential Cold-Formed Steel Framing", North American Steel Framing Alliance, 2000.

[2] AISI, "Shear Wall Design Guide", American Iron and Steel Institute, 1998.

[3] Serrette, R. and Ogunfunmi K., "Shear Resistance of Gypsum-sheathed Light-gauge Steel Stud Walls", Journal of Structural Engineering, 1996, Vol. 122, No. 4, pp. 383-389.

[4] Serrette, R., Encalada, J., Juadines, M., and Nguyen, H., "Static Racking Behavior of Plywood, OSB sheathing, Gypsum, and Fiberboard Walls with Metal Framing", Journal of Structural Engineering, 1997, Vol. 123, No. 8, pp. 1079-1086.

[5] Xia, B.Q. and Dong, J., "Finite Element Analysis of the Lateral Force Resistance of Light Gauge Steel Framed Compound Bearing Walls”, Building Structure, 2004, Supplement (8), pp. 334-337 (in Chinese).

[6] Emad, F.G.., Adrian, M.C., and Colin, F.D., "Lateral behavior of Plasterboard-clad Residential Steel Frames", Journal of Structural Engineering, 1999, Vol. 125, No. 1, pp. 32-39.

[7] JGJ 101-96, "Chinese Specification of Testing Methods for Earthquake Resistant Building”, 2006 (in Chinese).

[8] ANSYS version 10.0, "Finite Element Analysis Software", ANSYS Inc., 2006.

[9] Kasal, B. and Leichti, R.J., "Nonlinear Finite Element Model for Light-Frame Stud Walls", Journal of Structural Engineering, 1992, Vol. 118, No. 11, pp. 3122-3135.

[10] Thomas, W.H., "Concentrated Load Capacity and Stiffness of OSB: Calculation versus Test", Journal of Structural Engineering, 2002; Vol. 128, No. ST7, pp. 908-912.

[11] Zhou, T.H. and He, B.K., "Test Report of the Shear Resistance of Cold-formed Steel Stud Wall”, Report of Xi'an University of architecture \& technology, 2004 (in Chinese).

[12] The Japan Iron and Steel Federation, "Design Guide for Thin Light-gauge Steel Construction", Japan: Gihodo Shuppan Co. Ltd, 2002. 